\title{
Assessment of physico-chemical quality of borehole and spring water sources supplied to Robe Town, Oromia region, Ethiopia
}

\author{
Dagim Abera Shigut ${ }^{1} \cdot$ Geremew Liknew $^{2} \cdot$ Dejene Disasa Irge $^{2} \cdot$ Tanweer Ahmad $^{2}$
}

Received: 8 December 2015/Accepted: 10 November 2016/Published online: 30 November 2016

(c) The Author(s) 2016. This article is published with open access at Springerlink.com

\begin{abstract}
The study was carried out to find the physicochemical water quality of borehole and spring water supplied to Robe Town. For this study, a total of six water samples were collected from three borehole and three spring water sources. The analyses for 14 physico-chemical parameters, $\mathrm{pH}$, turbidity, electrical conductivity, total dissolved solids, total suspended solids total hardness cations $\left(\mathrm{Ca}^{2+}, \mathrm{Mg}^{2+}\right)$, anions $\left(\mathrm{NO}_{2}{ }^{-}, \mathrm{NO}_{3}{ }^{-}, \mathrm{SO}_{4}{ }^{2-}\right.$ and $\mathrm{PO}_{4}{ }^{3-}$ ) and heavy metals ( $\mathrm{Fe}$ and $\left.\mathrm{Mn}\right)$, were done in the laboratory by adopting standard procedures suggested by the American Public Health Association (APHA). Descriptive statistics were used to describe data, while Pearson correlation was used to determine the influences of the physico-chemical variables. The single factor analysis of variance ( $t$ test) was used to determine possible differences between the borehole and spring water, while means plots were used for further structure detection. From the total samples analyzed, most of the samples comply with the water quality guidelines of Ethiopian limit, WHO and U.SEPA. The $\mathrm{pH}$ of the water samples from borehole groundwater source was found to be slightly acidic and bove the maximum permissible limit (MPL). High concentration of $\mathrm{Fe}$ and Mn that exceeds the MPL set by WHO was found in the three boreholes. The spring water sources were found to be better for drinking than borehole water sources.
\end{abstract}

Tanweer Ahmad

tanweerakhan@gmail.com

1 Environmental Science, School of Natural Science, Madda Walabu University, Bale-Robe, Ethiopia

2 Department of Chemistry, School of Natural Science, Madda Walabu University, Bale-Robe, Ethiopia
Keywords Robe Town · Water quality · Borehole · Groundwater $\cdot$ Spring water

\section{Introduction}

Water is the most essential element for the existence of life on Earth. Though $80 \%$ of the Earth's surface is covered by water, the freshwater supply has increasingly become a limiting factor. About 1 billion people are without safe drinking water worldwide. The vast majority of these people are located in sub-Saharan Africa, South Asia and East Asia. Countless lives are lost annually due to drinking and using contaminated water (WHO 2006). To provide safe drinking water especially to rural populations, groundwater has been sought as the source in many developing and underdeveloped countries. Groundwater quality in a region is largely determined by both natural processes (dissolution and precipitation of minerals, groundwater velocity, quality of recharge waters and interaction with other types of water aquifers) and anthropogenic activities (Andrade et al. 2008; Devic et al. 2014).

In Ethiopia, the most common source of drinking water for the rural people is groundwater from borehole (deep wells), shallow wells and springs (Dzwairo et al. 2006). Groundwater is usually consumed without any form of treatment. Approximately, 2.2 billion people are without adequate sanitation in the world. In Ethiopia, the majority of people in rural areas and high-density townships in urban areas use pit latrines which are often in a state of disrepair and without hygiene (Abatneh et al. 2014; Lungu et al. 2008). In the rainy season, fecal matter from pit latrines and open sources is washed into water bodies, thereby contaminating the water (Dzwairo et al. 2006). 
One of the most important environment issues today is groundwater contamination and the diversity of contaminants that affect water resources. The natural chemical quality of groundwater is generally good, but elevated concentrations of a number of constituents can cause problems for water use. Intensive irrigated agricultural discharges into the groundwater can bring about considerable change in the groundwater quality. These anthropogenic activities on the groundwater pose serious threat to the groundwater users. Once the groundwater is contaminated, its quality cannot be restored by stopping the pollutants from the sources. It therefore becomes imperative to regularly monitor the quality of groundwater and to devise ways and means to protect it (Bairu et al. 2011).

In the present work, attempts have been made to evaluate the water quality of groundwater resources in Robe Town which has not been reported so far. The various physico-chemical groundwater quality parameters were assessed and the values obtained are compared with the permissible/desirable values prescribed by the Ethiopian and World Health Organization (WHO) guidelines to ensure the quality of groundwater for its use in domestic purposes. Moreover, it provides a hint on the relationships of physico-chemical parameters like $\mathrm{pH}$, turbidity, EC, TDS, TSS, hardness, calcium, magnesium, nitrate, nitrite, phosphate, sulfate, iron and manganese between each other other. It will give information about the differences between the borehole and the spring water sources by comparing one another to indicate which water source is better for drinking. Acquiring the relationship between various physico-chemical parameters helps in reducing the uncertainties associated with decision making and also in promoting advancement in research. The study provides baseline information about water quality for the welfare of the society and that may also help in future water resource planning for the area.

\section{Description of the study area}

Robe is one of the largest developing towns in Bale zone of Oromia region in Ethiopia. It is located $430 \mathrm{~km}$ to the southeast of Addis Ababa, the capital city of Ethiopia. The town has four kebeles with a population of approximately 58,239 (FDRE CSA, 2007). It is used as a residence for different social, economic, governmental and nongovernmental institutions. It is one of the fast growing towns of the Oromia region. According to the Industry and Urban Development Bureau of Oromia, standard assigning office, it is grouped under the towns ranked B.

The town is found between $7^{\circ} 7^{\prime} \mathrm{N}$ latitude and $40^{\circ} 0^{\prime} \mathrm{E}$ longitude. The topographic elevation of the town ranges from $2270 \mathrm{~m}$ up to $2690 \mathrm{~m}$ above sea level with mean annual temperature of $15^{\circ} \mathrm{C}$. It experiences cool temperature and has a mean annual rainfall of $1100 \mathrm{~mm}$. It covers a total area of land of $80,240 \mathrm{~km}^{2}$. The town is found in the climatic subtropical zone ("weynadega"). According to the data of the Robe meteorology station, the major rainy seasons are in autumn from February to May, and summer from June to September.

\section{Water point sources}

The Robe Town drinking water supply comes from six water point sources. The three borehole water sources are located in the southwest direction of the town and three spring water sources are located in the northwest of the town. These water point sources are indicated in Table 1.

\section{Materials and methods}

A total of six water samples were collected from the six water point sources of two different areas, namely Mio area (SSP4, SSP5 and SSP6) spring water and Technique area (BSP1, BSP2 and BSP3) borehole during March 2015 and analyzed to understand the physico-chemical variations of water quality parameters using standard methods (APHA 1995). Samples were collected in 1 L-capacity high-density polyethylene (HDPE) bottles. Prior to collection, the bottles were thoroughly washed with dilute $\mathrm{HNO}_{3}$ acid and then with distilled water in the laboratory before sample filling. The bottles were immediately sealed after collecting the sample to avoid reaction with the atmosphere. The sample bottles were labeled systematically. The collected samples were analyzed in the laboratory for various physico-chemical parameters. During sample collection, handling, preservation and analysis, standard procedures recommended by the American Public Health Association (APHA 1995) were followed to ensure data quality and consistency.

The $\mathrm{pH}$ of the water was measured at the field using AQUALYTICAL10pH portable $\mathrm{pH}$ meter. The EC and TDS were estimated by the HQ403D (HQ403D 53000000 $\mathrm{HACH}$ ) instrument. Turbidity was measured using

Table 1 Location of water point sources

\begin{tabular}{ll}
\hline Water point sources & Label \\
\hline Borehole sample point in Bale zone water office & BSP1 \\
Borehole sample point at Robe Technique School & BSP2 \\
Borehole sample point at Radio station & BSP3 \\
MedaWerabo spring water sample point & SSP4 \\
Oda spring water sample point & SSP5 \\
Chele spring water sample point & SSP6 \\
\hline
\end{tabular}




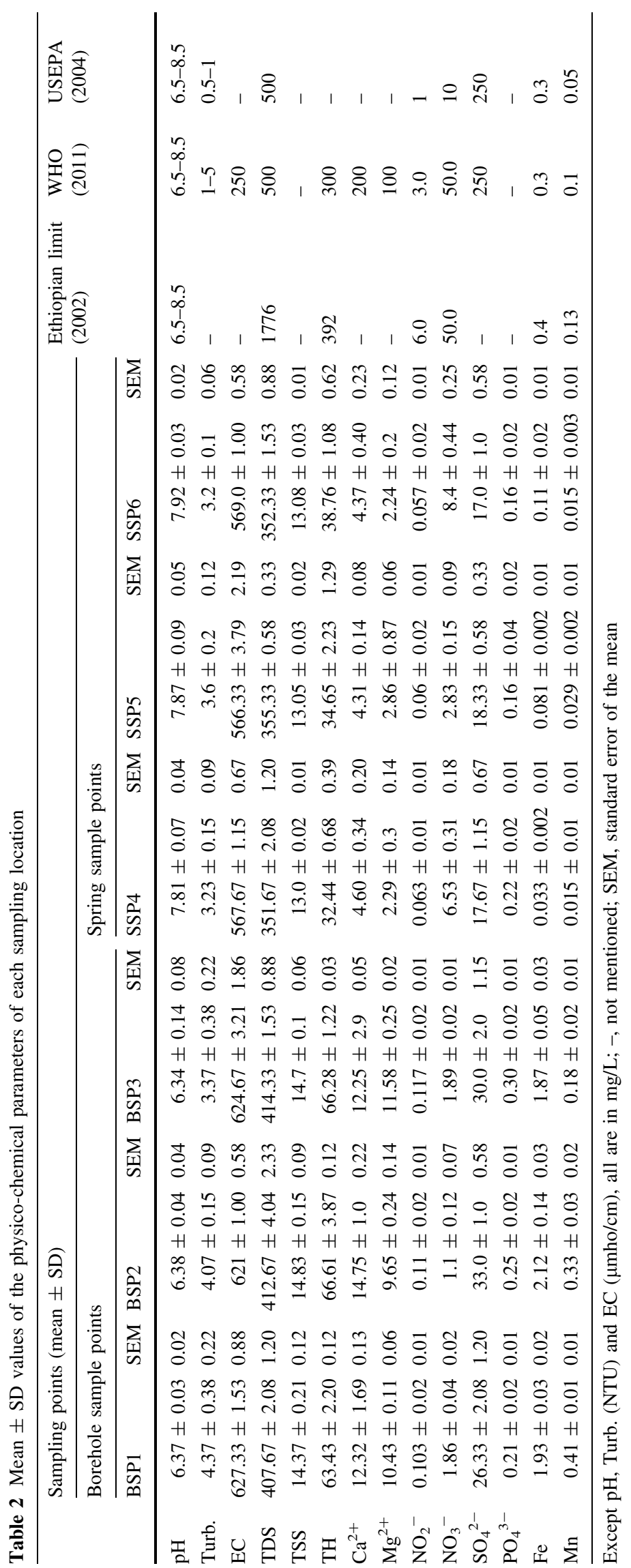


AquaFluor model 8000-010 instrument. Total suspended solid (TSS) was found using the gravimetric method. The total hardness $(\mathrm{TH})$ was estimated by the titrimetric method using EDTA. $\mathrm{NO}_{2}{ }^{-}, \mathrm{NO}_{3}{ }^{-}, \mathrm{SO}_{4}{ }^{2-}$ and $\mathrm{PO}_{4}{ }^{3-}$ were analyzed in the laboratory using the standard methods suggested by the American Public Health Association (APHA 1995). The concentrations of the common cations $\left(\mathrm{Ca}^{2+}\right.$ and $\mathrm{Mg}^{2+}$ ) and metals ( $\mathrm{Fe}$ and $\mathrm{Mn}$ ) were measured with the help of flame atomic absorption spectrometer (AA320N SHANGHAI General Analytical Instrument Factory). All the water quality parameters are expressed in $\mathrm{mg} / \mathrm{L}$, except $\mathrm{EC}, \mathrm{T}$ and $\mathrm{pH}$. All statistical analyses were performed using the computer program of SPSS 16.0 for Windows, Origin 6 and Microsoft Office Excel 2010.

\section{Results and discussion}

\section{Results of physico-chemical parameters}

The samples collected from borehole and spring water of Robe Town were analyzed for 14 physico-chemical parameters. Table 2 shows the results of both physical and chemical parameters found in descriptive statistics [Mean \pm standard deviation (SD)]. The results obtained for the six water point sources (borehole and spring water) shows the characteristics of the overall water quality.

The minimum and maximum values in the borehole and spring water samples of $\mathrm{pH}$ ranged between 6.34-6.37 and 6.34-7.92, turbidity between 4.07-4.37 NTU and 3.2-3.6 NTU, EC between $627.33-621 \mu \mathrm{mho} / \mathrm{cm}$ and $566.33-569$ $\mu \mathrm{mho} / \mathrm{cm}$, TDS between 407.67-414.33 and $355.33-351.67 \mathrm{mg} / \mathrm{L}$ and TSS between 14.37-14.83 and $13.00-13.08 \mathrm{mg} / \mathrm{L}$, respectively. Total hardness $(\mathrm{TH})$, both calcium and magnesium hardness in terms of calcium carbonate concentration, ranged between 63.63-66.61 and $32.44-38.76 \mathrm{mg} / \mathrm{L}$ found in the borehole and spring water samples, respectively. The cations $\left(\mathrm{Ca}^{2+}, \mathrm{Mg}^{2+}\right)$ in the borehole and spring water samples ranged from 12.65 to 14.08 and 4.31 to $4.6 \mathrm{mg} / \mathrm{L}, 9.65$ to 11.58 and 2.24 to $2.86 \mathrm{mg} / \mathrm{L}$, respectively. The amounts of anions present in the water also have both narrow and wide ranges. The maximum and minimum concentration in the borehole and spring water samples of $\mathrm{NO}_{2}{ }^{-}$ranged between $0.11-0.12$ and $0.05-0.06 \mathrm{mg} / \mathrm{L}, \mathrm{NO}_{3}{ }^{-}$ between $1.10-1.89$ and $2.83-8.40 \mathrm{mg} / \mathrm{L}, \mathrm{SO}_{4}{ }^{2-}$ between 26.33-33.00 and $17.00-18.33 \mathrm{mg} / \mathrm{L}$ and $\mathrm{PO}_{4}{ }^{3-}$ between $0.21-0.30$ and $0.16-0.22 \mathrm{mg} / \mathrm{L}$, respectively. The heavy metals ( $\mathrm{Fe}$ and $\mathrm{Mn}$ ) in the borehole and spring water samples varied from 1.87 to 2.12 and 0.03 to $0.08 \mathrm{mg} / \mathrm{L}, 0.18-0.41$ and $0.02-0.03 \mathrm{mg} / \mathrm{L}$, respectively. The ranges of the heavy metals in the borehole water samples $\mathrm{Fe}(1.87-2.12 \mathrm{mg} / \mathrm{L})$ and $\mathrm{Mn}$ $(0.18-0.41 \mathrm{mg} / \mathrm{L})$ were found above the maximum permissible limits of the WHO.

\section{Spatial variations in the physico-chemical characteristics of sampling sources}

There are significant spatial variations in the physicochemical characteristics of deep borehole groundwater and spring water sources. The significant spatial variations were tested using the test of homogeneity in mean variance of the quality parameters of the borehole and spring water samples. Spatial variations were observed in the concentrations of the physico-chemical variables of borehole and spring water of the study area.

\section{pH}

$\mathrm{pH}$ is a term used universally to express the intensity of the acid or alkaline condition of a solution. The $\mathrm{pH}$ values of water samples were found to vary from 6.34 to 7.92 . The least $\mathrm{pH}$ value $6.34 \pm 0.14$ was recorded in the borehole water sample (BSP3), while the maximum value of $7.92 \pm 0.03$ was recorded in the spring water (SSP6) (Fig. 1). From the above result, three of the water samples analyzed were slightly acidic and found to be above the MPL set by the Ethiopian limit, WHO and U.S EPA. Longterm exposure to $\mathrm{pH}$ beyond the permissible limit affects the mucous membrane of cells (Nishtha et al. 2012).

This may be attributed to anthropogenic activities such as sewage disposal and use of fertilizers in agricultural lands of the study area. The general increase of $\mathrm{pH}$ in a sedimentary terrain is related to weathering of plagioclase feldspar in sediments. This is aided by dissolved atmospheric carbon dioxide resulting in the release of sodium and calcium, which progressively increases $\mathrm{pH}$ and alkalinity of the groundwater (Venkatramanan et al. 2013). The water from the borehole groundwater sources can also easily corrode the water piping due to the acidic nature of the water. Damaged metal pipes due to acidic $\mathrm{pH}$ values

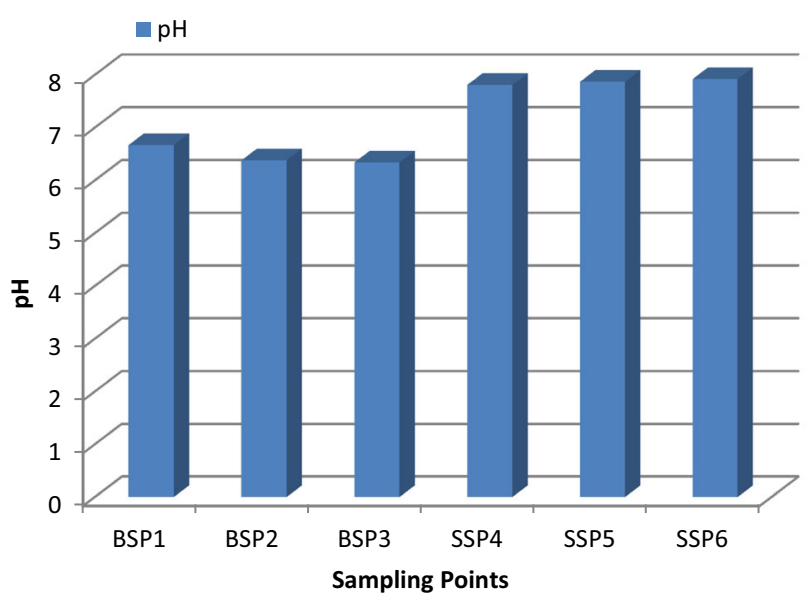

Fig. 1 Spatial variation in $\mathrm{pH}$ of borehole and spring water sources 
Fig. 2 Spatial variation in a turbidity, b EC, $\mathbf{c}$ TDS and d TSS of borehole and spring water sources

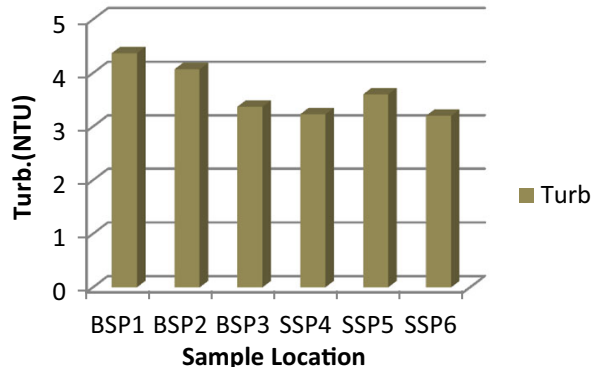

(a)

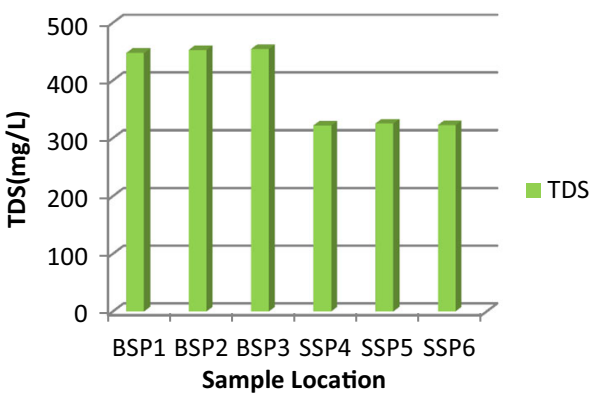

(c)

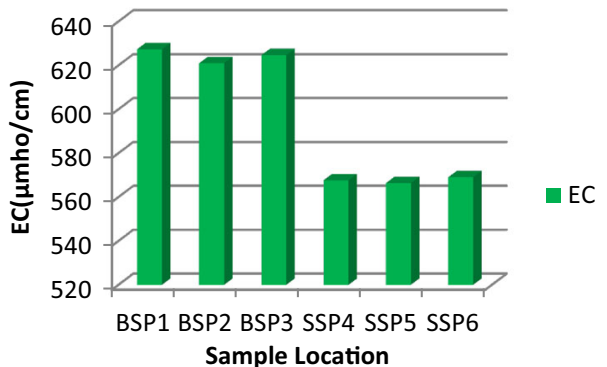

(b)

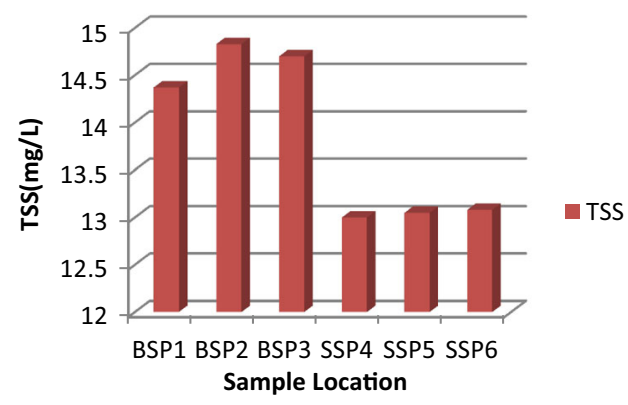

(d) can also lead to esthetic problems, causing water to have a metallic or sour taste (Sabrina et al. 2013).

\section{Turbidity}

The turbidity is one of the important physical parameters for water quality, defining the presence of suspended solids in water and causes the muddy or turbid appearance of water body (Tiwari et al. 2015). In the present study area, the turbidity was found varied between the borehole and spring water sources (Fig. 2a). The highest turbidity was recorded in the borehole groundwater source (BSP1) and the lowest turbidity was recorded in the spring water source (SSP4). All the samples analyzed were found within the limits prescribed by WHO standards (1-5 NTU). From the result found, the water from the borehole groundwater source was slightly more turbid than the spring water source. This slight turbidity indicates that there may be the presence of inorganic particulate matter and non-soluble metal oxides. The consumption of high turbid water may cause a health risk, as excessive turbidity can protect pathogenic microorganisms from effects of disinfectants Singh et al. 2013; Tiwari and Singh 2014).

\section{Total suspended solid (TSS)}

TSS is the turbidity caused due to silt and organic matter. In the study area, maximum TSS concentrations were found in the borehole groundwater sample (BSP2) and minimum TSS concentrations were found in the spring water source (SSP4) of 14.83 and $13.00 \mathrm{mg} / \mathrm{L}$, respectively (Fig. 2d). Minimum variation was observed between the borehole groundwater and spring water source. No guideline value is set for TSS because of its less health concern.

\section{Total dissolved solids (TDS)}

Total dissolved solids indicate the salinity behavior of groundwater. In the study area, TDS values varied from $351.67 \mathrm{mg} / \mathrm{L}$ (in SSP4) to $414.33 \mathrm{mg} / \mathrm{L}$ (in BSP3) (Fig. 2c). All the samples analyzed were found within the standard permissible limit. The borehole groundwater samples have the highest TDS values than the spring water source. The presence of TDS above this limit in groundwater would cause undesirable taste and gastrointestinal irritation (Selvakumar et al. 2014).

\section{Electrical conductivity (EC)}

EC denotes the conducting capacity of water. EC is a measure of total dissolved solids (TDS) i.e., it depends upon the ionic strength of the solution. Increase in the concentration of dissolved solids increases the ionic strength of the solution. In the study area, EC was in the range of $566.33 \mu \mathrm{mho} / \mathrm{cm}$ (at SSP4) to $627.33 \mu \mathrm{mho} / \mathrm{cm}$ (at BSP1). Borehole groundwater sample found behind the zonal water office has the highest value of EC, whereas the spring water source at SSP4 has the lowest value. TDS and EC are usually interlinked to one another. This behavior was also observed in this analysis (Fig. 2b). The increase in

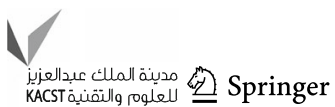


TDS and EC increases the corrosive nature of water. Unusual taste, odor and feel problems usually due to total dissolved solids and higher EC indicate the presence of dissolved minerals (WHO 2011a). Figure 2 shows that the higher TDS concentration indicates increase in the electrical conductivity of water.

\section{Total hardness (TH)}

The total hardness (TH) is an important parameter of water quality whether it is to be used for domestic, industrial or agricultural purposes. Hardness of the water is the property attributed to the presence of alkaline earths. It is the property of water by which it prevents lather formation with soap and increases the boiling point of water. Water can be classified into soft $(75 \mathrm{mg} / \mathrm{L})$, moderately hard (75-150 mg/L), hard (150-300 mg/L) and very hard (300 mg/L) based on hardness (Sawyer and McCarty 1967). The hardness of groundwater in the study area varied from 32.44 to $66.61 \mathrm{mg} / \mathrm{L}$ (Fig. 3). From the result obtained, the analyzed borehole groundwater samples have a higher $\mathrm{TH}$ concentration. The high hardness may cause encrustation on water supply distribution systems. Longterm consumption of extremely hard water might lead to an increased incidence of urolithiasis, anencephaly, prenatal mortality, some types of cancer and cardiovascular disorders (Agrawal and Jagetia 1997).

\section{Calcium and magnesium $\left(\mathrm{Ca}^{2+}, \mathrm{Mg}^{2+}\right)$}

Calcium and magnesium are directly related to hardness. In the study area, calcium ion concentration ranged between $4.31 \mathrm{mg} / \mathrm{L}$ at the spring water source (at SSP4) and $14.08 \mathrm{mg} / \mathrm{L}$ at the borehole water source (BSP2) and was found to be below the permissible limit. Magnesium ion content in the water samples ranged from $2.24 \mathrm{mg} / \mathrm{L}$ at the spring water source (at SSP6) to $11.58 \mathrm{mg} / \mathrm{L}$ at the

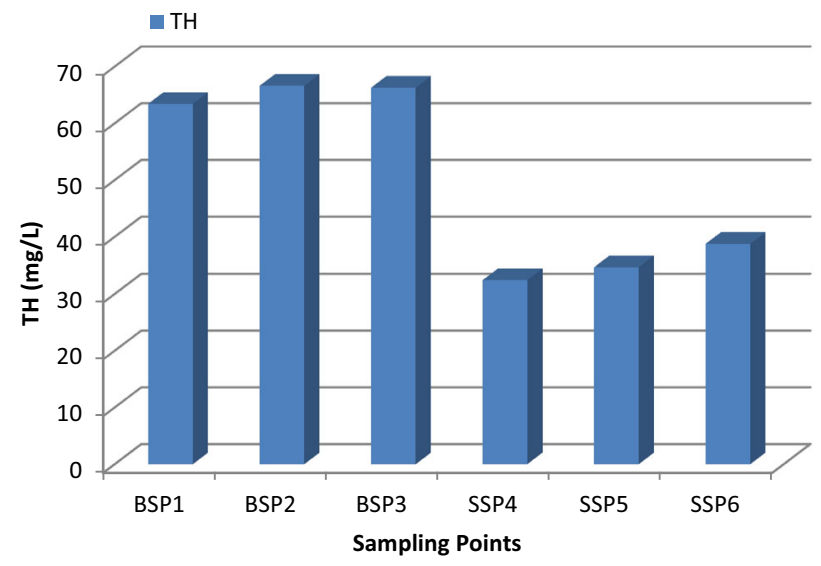

Fig. 3 Spatial variation in $\mathrm{TH}$ of borehole and spring water sources borehole water source (BSP3) and was found to be within the prescribed limit (Fig. 4). The borehole groundwater samples analyzed have the highest values of both calcium and magnesium concentrations. This is mainly due to the depth of the water in contact with the rock surface aquifer. The principal sources of calcium and magnesium in most of the groundwater samples are detrital minerals such as plagioclase feldspar, pyroxene, amphibole and garnet (Hounslow 1995).

\section{Nitrite $\left(\mathrm{NO}_{2}{ }^{-}\right)$and nitrate $\left(\mathrm{NO}_{3}{ }^{-}\right)$}

Groundwater contains nitrate due to leaching of nitrate with the percolating water. Groundwater can also be contaminated by sewage and other wastes rich in nitrates (Sirajudeen and Mubashir 2013). Nitrate commonly occurs naturally in groundwater, but high concentration might be associated with animal and human waste, open septic or sewage systems and fertilization of farms (Akaahan et al. 2010). The maximum nitrite concentration was found to be $0.103 \mathrm{mg} / \mathrm{L}$ at the borehole water source (at BSP1), while the least concentration of $0.06 \mathrm{mg} / \mathrm{L}$ was recorded at the spring water source (at SSP6). The nitrate content in the study area varied in the range $1.1 \mathrm{mg} / \mathrm{L}$ at the borehole water source (at BSP2) to $8.4 \mathrm{mg} / \mathrm{L}$ at the spring water source (at SSP6) and was found within the prescribed limit (Fig. 5). The highest nitrate content in the study area was found to be in the spring water sources of SSP4 $(6.53 \mathrm{mg}$ / L) and SSP6 $(8.4 \mathrm{mg} / \mathrm{L})$ and was within the prescribed limit (Fig. 5). Excessive $\mathrm{NO}_{3}{ }^{-}$in drinking water can cause a number of disorders including methemoglobinemia in infants, gastric cancer, goiter, birth malformations and hypertension (Majumdar and Gupta 2000).

\section{Sulfate}

Sulfate occurs naturally in water as a result of leaching from gypsum and other common minerals. Discharge of industrial wastes and domestic sewage tends to increase its concentration (WHO 1999).In the study area, the sulfate concentration varied between $33.0 \mathrm{mg} / \mathrm{L}$ at the borehole water source(at BSP2), while the least concentration of $17.0 \mathrm{mg} / \mathrm{L}$ was recorded at the spring water source(at SSP6) (Fig. 5c). The sulfate concentration both in the borehole and spring water sources was found to be within the secondary drinking water regulation set by the U.S EPA prescribed limit (U.SEPA 2004).

\section{Phosphate}

Phosphate may occur in groundwater as a result of domestic sewage, detergents and agricultural effluents with fertilizers (Murhekar 2011). Normally, groundwater 
Fig. 4 Spatial variation in a $\mathrm{Ca}^{2+}$ and $\mathbf{b ~} \mathrm{Mg}^{2+}$ of borehole and spring water sources

Fig. 5 Spatial variation in a $\mathrm{NO}_{2}{ }^{-}, \mathbf{b ~} \mathrm{NO}_{3}{ }^{-}, \mathbf{c ~} \mathrm{SO}_{4}{ }^{2-}$ and d $\mathrm{PO}_{4}{ }^{3-}$ of borehole and spring water sources

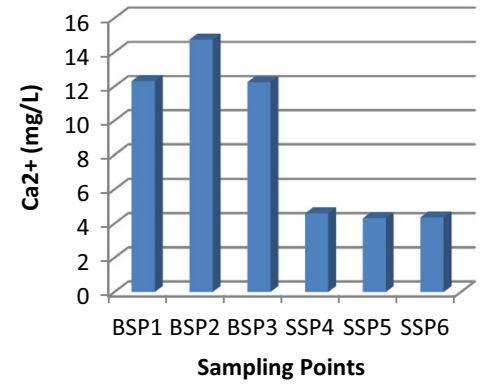

(a)

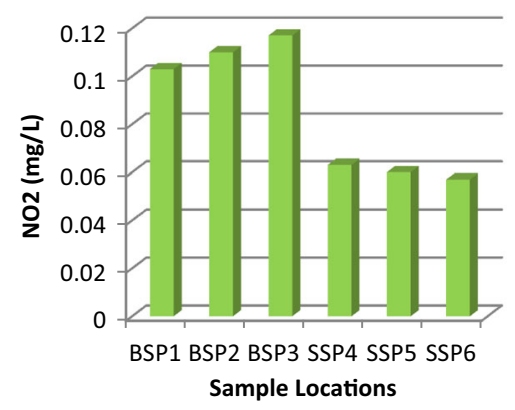

(a)

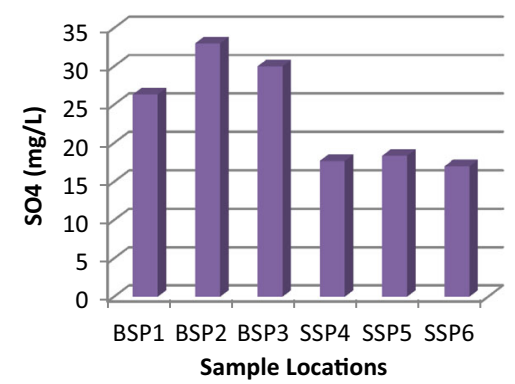

(c)

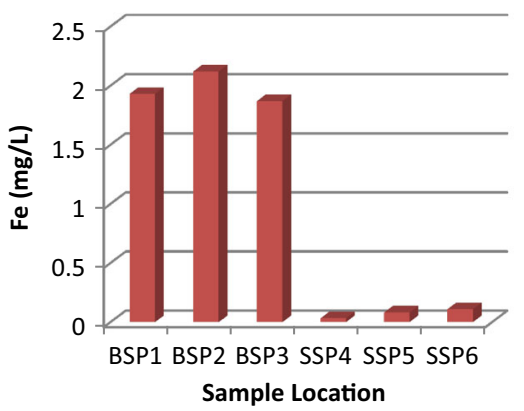

(a)

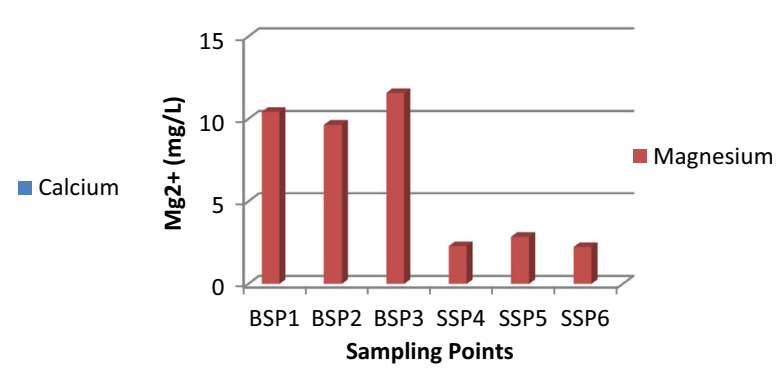

(b)

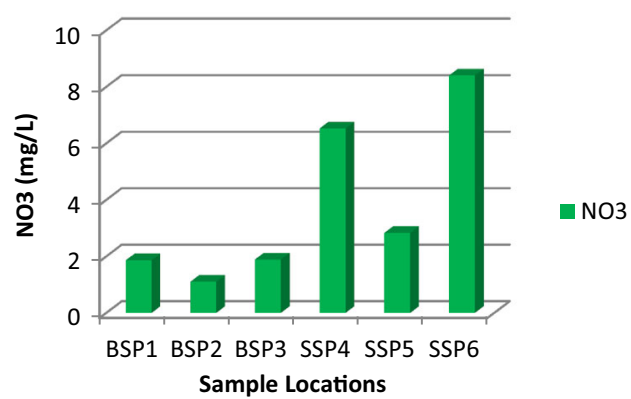

(b)

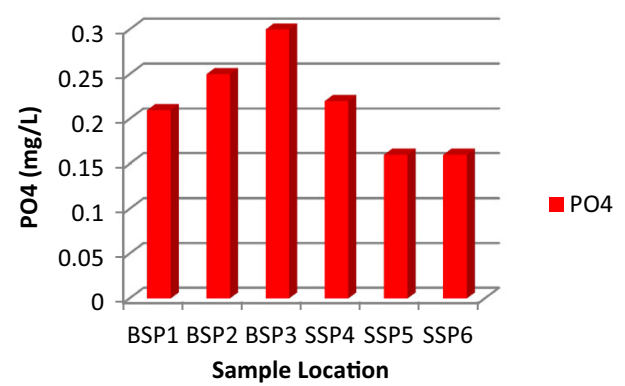

(d)

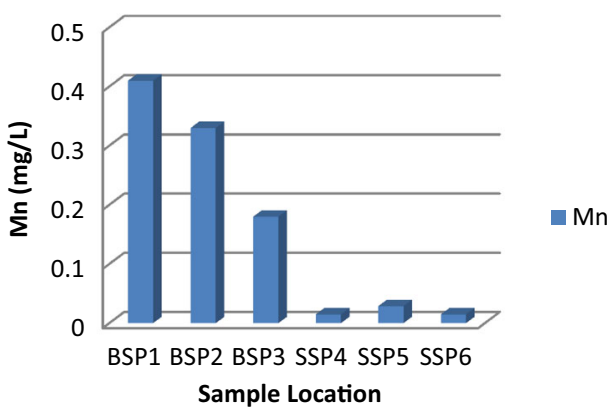

(b) contains only a minimum phosphorus level because of the low solubility of native phosphate minerals and the ability of soils to retain phosphate (Devendra et al. 2014).In the study area, the phosphate concentration varied between $0.30 \mathrm{mg} / \mathrm{L}$ at the borehole water source (at BSP3) and $0.16 \mathrm{mg} / \mathrm{L}$ at the spring water source (at SSP5 and SSP6) and was within the prescribed limit (Fig. 5d).

\section{Iron (Fe) and manganese (Mn)}

In the study area, the maximum $\mathrm{Fe}$ concentration of $2.12 \mathrm{mg} / \mathrm{L}$ (BSP2) and a minimum concentration of $0.033 \mathrm{mg} / \mathrm{L}$ (SSP4) was recorded (Fig. 6a). From the samples analyzed, three of the samples (BSP1, BSP2 and BSP3) were found to be above the permissible limit set by 
the Ethiopian limit, WHO and U.S EPA. The highest Fe concentration was observed in the deep borehole groundwater sources. This is mainly due to the rock structure of the area and the depth of the aquifer.

In the study area, the minimum and maximum $\mathrm{Mn}$ concentrations of 0.015 and $0.41 \mathrm{mg} / \mathrm{L}$ were recorded in the spring water of SSP4 and SSP6 and deep borehole BSP1, respectively (Fig. 6b). A high concentration of $\mathrm{Fe}$ and Mn that exceeds the MPL set by WHO was found in the three boreholes. This is as a result of the depth of the water that is in contact with the rock surface aquifer. These high concentrations of the metals were the major esthetic problems that lead to taste and odor problems. No healthbased guideline value is proposed for iron, although the taste (organoleptic problem) is affected above $0.3 \mathrm{mg} / \mathrm{L}$ (WHO 2011b).

\section{Comparison of the borehole and spring water}

The significant difference in the physico-chemical qualities of the borehole and spring water sources of the study area was tested using Student's $t$ test. This was done to ascertain, if there was any significant difference in the physicochemical water quality parameters of the borehole and spring water sources supplied to Robe Town. To achieve this, pairwise analysis was conducted.

The pairwise analysis reveals both significant correlations " $\mathrm{r}$ " ranging from 0.998 to 0.999 (strong correlation) and pooled significant depth-related difference of 0.042 (significant $t$ value ranged from 0.037 to 0.052 ) at $P<0.05$. Since the pooled significant $t$ value $(0.042)$ is less than (0.05), there is significant difference in the physico-chemical qualities of the borehole and spring water sources. This indicates that the qualities of the water sources are determined by the concentration of the indicator parameters present in them. Hence, differences in the means of the parameters tested indicate differences in the water qualities from the borehole and spring water sources.

\section{Correlation matrix of the physico-chemical parameters}

The interactions within and between the physico-chemical parameters of the different water sources were further verified by Pearson correlation. The Pearson's correlation $(r)$ is used to find a correlation between at least two continuous variables. The value for a Pearson's correlation can fall between 0.00 (no correlation) and 1.00 (perfect correlation).More precisely, it can be said that parameters showing $r>0.7$ are considered to be strongly correlated, whereas when $r$ has a value between 0.5 and 0.7, a moderate correlation is shown to exist (Helena et al. 2000). The test revealed several significant interactions among the physico-chemical variables in the water samples of the study area. Many of the physico-chemical parameters showed strong correlations with each other (Table 3).

At $P<0.01, \mathrm{pH}$ correlated negatively with EC $(r=-996), \quad$ TDS $\quad(r=-998), \quad$ TSS $\quad(r=-983), \mathrm{TH}$ $(r=-995), \quad \mathrm{Ca} \quad(r=-998), \quad \mathrm{Mg} \quad(r=-995), \quad \mathrm{NO}_{2}$ $(r=-976), \mathrm{SO}_{4}(r=-950), \mathrm{PO}_{4}(r=-766)$ and $\mathrm{Fe}$ $(r=-993)$, The other physico-chemical parameters correlated with several others at $P<0.01$, except turbidity with pH, EC, TDS, $\mathrm{Ca}, \mathrm{Mg}, \mathrm{TH}, \mathrm{NO}_{2}, \mathrm{NO}_{3}, \mathrm{SO}_{4}, \mathrm{PO}_{4}$ and $\mathrm{Fe}, \mathrm{NO}_{3}$ with $\mathrm{pH}, \mathrm{EC}, \mathrm{TSS}, \mathrm{Ca}, \mathrm{Mg}, \mathrm{TH}, \mathrm{SO}_{4}, \mathrm{PO}_{4}, \mathrm{Fe}$ and $\mathrm{Mn}, \mathrm{PO}_{4}$ with $\mathrm{pH}$, turbidity, EC, TSS, $\mathrm{Ca}, \mathrm{Mg}, \mathrm{TH}, \mathrm{NO}_{3}$, $\mathrm{SO}_{4}, \mathrm{Fe}$ and $\mathrm{Mn}$ and $\mathrm{Mn}$ with $\mathrm{NO}_{2}, \mathrm{NO}_{3}, \mathrm{SO}_{4}$ and $\mathrm{PO}_{4}$ which did not show significant correlations at either $P<0.05$ or $<0.01$.

Since at $P<0.01$ or $P<0.05$, most of the physicochemical parameters correlated with several others parameters, there were significant interactions between the physico-chemical parameters in the borehole groundwater and spring water samples of the study. This confirms that the presence of certain pollution indicators will influence the presence or increase of some other parameters. The increase of one physico-chemical parameter indicates the increase or decrease of another parameter. For example, a higher TDS means that there are more cations than anions in the water, and with more ions in the water the water's EC increases. By measuring the water's EC, we can indirectly determine its TDS concentration. At a high TDS concentration, water becomes saline.

\section{Conclusion}

In this study, water samples from deep borehole groundwater and spring water sources of six different locations were taken. From these water samples, some selected physico-chemical parameters $(\mathrm{pH}$, turbidity, EC, TDS, TSS, TH, $\mathrm{Ca}, \mathrm{Mg}, \mathrm{NO}_{2}, \mathrm{NO}_{3}, \mathrm{SO}_{4}, \mathrm{PO}_{4}, \mathrm{Fe}$ and $\mathrm{Mn}$ ) were analyzed to predict the water quality status of Robe Town. From the analysis performed, most of the physico-chemical parameters analyzed comply with national and international drinking water guidelines, except $\mathrm{pH}$, iron and manganese. The highest iron and manganese concentration were recorded in the three borehole water sources. These concentrations exceeded the MPL set by the Ethiopian limit, WHO and U.S EPA drinking water guidelines.

Based on the results obtained from this study, the water quality of borehole water sources differed from that of spring water source. These differences were observed from the variations in the physico-chemical parameters analyzed from borehole and spring water sources. The borehole water sources were found to be slightly acidic (above the MPL) and have highest TDS, EC, TH, $\mathrm{Ca}$ and $\mathrm{Mg}$ 
Table 3 Correlation results of physico-chemical parameters

\begin{tabular}{|c|c|c|c|c|c|c|c|c|c|c|c|c|c|c|}
\hline & $\mathrm{pH}$ & Turb & $\mathrm{EC}$ & TDS & TSS & $\mathrm{TH}$ & $\mathrm{Ca}$ & $\mathrm{Mg}$ & $\mathrm{NO}_{2}$ & $\mathrm{NO}_{3}$ & $\mathrm{SO}_{4}$ & $\mathrm{PO}_{4}$ & $\mathrm{Fe}$ & $\mathrm{Mn}$ \\
\hline $\mathrm{pH}$ & 1 & & & & & & & & & & & & & \\
\hline Turb & -0.667 & 1 & & & & & & & & & & & & \\
\hline $\mathrm{EC}$ & $-0.996 * *$ & 0.677 & 1 & & & & & & & & & & & \\
\hline TDS & $-0.996 * *$ & 0.645 & $0.991 * *$ & & & & & & & & & & & \\
\hline TSS & $-0.983 * *$ & 0.608 & $0.973 * *$ & $0.992 * *$ & 1 & & & & & & & & & \\
\hline $\mathrm{TH}$ & $-0.985^{* *}$ & 0.632 & $0.986^{* *}$ & $0.992 * *$ & $0.990 * *$ & 1 & & & & & & & & \\
\hline $\mathrm{Ca}$ & $-0.980 * *$ & 0.692 & $0.969 * *$ & $0.982 * *$ & $0.989 * *$ & $0.978 * *$ & 1 & & & & & & & \\
\hline $\mathrm{Mg}$ & $-0.991 * *$ & 0.613 & $0.990 * *$ & $0.991 * *$ & $0.971 * *$ & $0.979 * *$ & $0.950 * *$ & 1 & & & & & & \\
\hline $\mathrm{NO}_{2}$ & $-0.976 * *$ & 0.538 & $0.959 * *$ & $0.983 * *$ & $0.978 * *$ & $0.958 * *$ & $0.953 * *$ & $0.980 * *$ & 1 & & & & & \\
\hline $\mathrm{NO}_{3}$ & 0.798 & -0.723 & -0.769 & $-0.812^{*}$ & -0.788 & -0.753 & -0.792 & -0.801 & $-0.823 *$ & 1 & & & & \\
\hline $\mathrm{SO}_{4}$ & $-0.950 * *$ & 0.588 & $0.928 * *$ & $0.966^{* *}$ & $0.987 * *$ & $0.956 * *$ & $0.980 * *$ & $0.929 * *$ & $0.964 * *$ & $-0.813^{*}$ & 1 & & & \\
\hline $\mathrm{PO}_{4}$ & -0.766 & 0.099 & 0.731 & 0.767 & 0.781 & 0.727 & 0.731 & 0.775 & $0.858^{*}$ & -0.540 & 0.788 & 1 & & \\
\hline $\mathrm{Fe}$ & $-0.993 * *$ & 0.698 & $0.990 * *$ & $0.994 * *$ & $0.990 * *$ & $0.992 * *$ & $0.993 * *$ & $0.976 * *$ & $0.961 * *$ & -0.794 & $0.964 * *$ & 0.721 & 1 & \\
\hline $\mathrm{Mn}$ & $-0.896^{*}$ & $0.907 *$ & $0.907 *$ & $0.874^{*}$ & $0.849 *$ & $0.874^{*}$ & $0.902^{*}$ & $0.852^{*}$ & 0.788 & -0.736 & 0.808 & 0.442 & $0.913 *$ & 1 \\
\hline
\end{tabular}

** Correlation is significant at the 0.01 level (2-tailed)

* Correlation is significant at the 0.05 level (2-tailed)

concentration. Therefore, the drinking water quality of the spring water sources is more preferable than the three deep borehole groundwater sources. Moreover, additional measures must be taken by the government and stake holders to improve the water quality of the town and to supply clean and safe water to the public that is free from health hazards.

Acknowledgements We are thankful to the Department of Chemistry, School of Natural Sciences, Madda Walabu University, BaleRobe, Ethiopia, for providing necessary facilities to carry out this research. The first author is grateful to the Research Directorate, Madda Walabu University, for providing financial support. The authors are very much thankful to the anonymous reviewers for their critical review and comments that helped immensely in improving the quality of the manuscript.

Open Access This article is distributed under the terms of the Creative Commons Attribution 4.0 International License (http:// creativecommons.org/licenses/by/4.0/), which permits unrestricted use, distribution, and reproduction in any medium, provided you give appropriate credit to the original author(s) and the source, provide a link to the Creative Commons license, and indicate if changes were made.

\section{References}

Abatneh Y, Sahu OP, Yimer S (2014) Purification of drinking water by low cost method in Ethiopia. Appl Water Sci 4:357-362

Agrawal V, Jagetia M (1997) Hydrogeochemical assessment of groundwater quality in Udaipur city, Rajasthan, India. Proceedings of National Conference on Dimension of Environmental Stress in India. Department of Geology, MS University, Baroda, pp 151-154

Akaahan TJ, Oluma HA, Sha'Ato R (2010) Physico-chemical and bacteriological quality of water from shallow wells in two rural communities in Benue State, Nigeria. Pak J Anal and Environ Chem 11(1):73-78

Andrade E, Palacio HAQ, Souza IH, Leao RA, Guerreio MJ (2008) Land use effects in groundwater composition of an alluvial aquifer by multivariate techniques. Environ Res 106:170-177

APHA (1995) Standard methods for the examination of water and wastewater, 19th edn. American Public Health Association, Washington, DC

Bairu GA, Nata T, Elias J (2011) Application of water quality index to assess suitability of groundwater quality for drinking purposes in Hantebet watershed, Tigray, Northern Ethiopia. J Food and Agri Sci 1(1):22-30

Devendra D, Shriram D, Atul K (2014) Analysis of ground water quality parameters: a Review. Res J Eng Sci 3(5):26-31

Devic G, Djordjevic D, Sakan S (2014) Natural and anthropogenic factors affecting the groundwater quality in Serbia. Sci Total Environ 468-469:933-942

Dzwairo B, Hoko Z, Love D, Guzha E (2006) Assessment of the impacts of pit latrines on groundwater quality in rural areas: a case study from Marondera district, Zimbabwe. Phys Chem Earth J 31:779-788

Helena B, Pardo R, Vega M, Barrado E, Fernandez JM, Fernandez L (2000) Temporal evolution of groundwater composition in alluvial aquifer (Pisuerga River, Spain) by principal component analysis. Water Res 49:359-372

Hounslow AW (1995) Water quality data-analysis and interpretation. Lewis Publishers, Boca Raton

Lungu K, Morse T, Grimason AM (2008) Ecological sanitationimplementation opportunities and challenges in Chikwawa, Malawi. Environ Health Int Magaz Int Federat Environ Health Cong 10(2):1-7

Majumdar D, Gupta N (2000) Nitrate pollution of ground water and associated human health disorders. Indian $\mathrm{J}$ Environ Health 42:28-39

Murhekar GH (2011) Assessment of physico-chemical status of ground water samples in Akot city. Res $J$ Chem Sci 1(4):117-124

Nishtha K, Lokhande RS, Dhar JK (2012) Physico-chemical, bacteriological and pesticide analysis of tap water in Millennium City Gurgoan, Haryana, India. Int Res J Environ Sci 1(2):1-7 
Sabrina S, Daniela P, Joseph M, Sieliechi M, Ngassoum B (2013) Assessment of physical-chemical drinking water quality in the Logone Valley (Chad-Cameroon). Sustainability 5:3060-3076

Sawyer CN, McCarty PL (1967) Chemistry of sanitary engineers, 2nd edn. McGraw Hill, New York

Selvakumar S, Ramkumar K, Chandrasekar N, Magesh NS, Kaliraj S (2014) Groundwater quality and its suitability for drinking and irrigational use in the Southern Tiruchirappalli district. Appl Water Sci, Tamil Nadu, India. doi:10.1007/s13201-014-0256-9

Singh PK, Tiwari AK, Panigarhy BP, Mahato MK (2013) Water quality indices used for water resources vulnerability assessment using GIS technique: a review. Int $J$ Earth Sci Eng 6(6-1):1594-1600

Sirajudeen J, Mubashir M (2013) Statistical approach and assessment of physico-chemical status of ground water in near proximity of South Bank Canal, Tamil Nadu, India. Archiv Appl Sci Res $5(2): 25-32$

Tiwari AK, Singh AK (2014) Hydrogeochemical investigation and groundwater quality assessment of Pratapgarh district, Uttar Pradesh. J Geol Soc India 83(3):329-343
Tiwari AK, Singh AK, Singh AK, Singh MP (2015) Hydrogeochemical analysis and evaluation of surface water quality of Pratapgarh district. Appl Water Sci, Uttar Pradesh. doi:10.1007/ s13201-015-0313-Z

U.SEPA (2004) Drinking Water Standards and Health Advisories, Office of Water. Environmental Protection Agency, Washington D.C

Venkatramanan S, Chung SY, Ramkumar T, Gnanachandrasamy G, Vasudevan S (2013) A multivariate statistical approaches on physicochemical characteristics of ground water in and around Nagapattinam district, Cauvery deltaic region of Tamil Nadu, India. Earth Sci Res J 17(2):97-103

WHO (2006) Guidelines for drinking water quality, First Addendum to Third Edition, vol 1 Recommendations. Available from:http:// www.who.int/water_sanitation_health/dwq/gdwq0506.pdf. Accessed June 2014

WHO (2011a) Guidelines for drinking-water quality, 4th edn. World Health Organization, Geneva

WHO (2011b) Manganese in drinking-water. Background document for development of WHO guidelines for drinking-water quality, Geneva 